\title{
Performance of Construction Companies in Southeast Asia using Static and Dynamic Panel Data
}

\author{
Beny Mulyana Sukandar ${ }^{1, *}$, Noer Azam Achsani ${ }^{2}$, Roy Sembel ${ }^{3}$, Bagus Sartono $^{4}$ \\ ${ }^{1}$ Civil Engineering Department, Polytechnic State of Bandung (POLBAN) \\ West Java, Indonesia \\ ${ }^{2}$ School of Business and Management (SB-IPB), Bogor Agricultural University \\ Indonesia \\ ${ }^{3}$ School of Business, IPMI International Business School \\ Jakarta, Indonesia \\ ${ }^{4}$ Department Statistics, Bogor Agricultural University \\ Indonesia \\ *Corresponding author's email: beny.sukandar [AT] yahoo.com
}

\begin{abstract}
Global competition has challenged the performance of construction companies in Southeast Asia. This research determines factors that influence the performance of construction companies. Data collections were obtained from stock exchanges of countries under the study from years 2013 to 2016. The research methods use static and dynamic panel data. The results reveal that financial performance of construction companies is affected by DER, interest rate and efficiency, while their market performance is influenced by growth of construction cost, interest rate and score of efficiency.
\end{abstract}

Keywords--- Performance, Constructions, Static and Dynamic Panel, Southeast Asia

\section{INTRODUCTION}

Construction is an activity whose end result is a building/construction that integrates with the place of occupation [10]. The results of the construction industry include buildings, roads, bridges, railways and railway bridges, tunnels, water and drainage buildings, sanitation buildings, airports, electricity and communication networks, and others. Construction is a sector that is predicted to continue to develop for the future with the increasingly complex development sectors: i.e. construction of transportation facilities and infrastructure, high-rise buildings, housing, factories and irrigation. The construction industry plays an important role in building infrastructure required in socio-economic development and contributing directly to economic growth [18] [16]. In addition, the construction industry also has links with many other sectors and is often referred to as a locomotive for commercial activities in these sectors [33].

The construction sector in Southeast Asian countries has increasingly intense global competition that is quite tight in the construction sector due to its high value. The Indonesian construction services market is the largest construction market in ASEAN and also the world number 4. Indonesia's construction market was around US \$ 267 billion in 2014 while China amounted to US \$ 1.78 trillion, Japan amounted to US \$ 742 billion, India amounted to US \$ 427 trillion and when compared to ASEAN countries including Thailand amounting to US \$ 33 billion, Malaysia amounted to US \$ 32 billion, Philippines at US \$25 billion, Singapore at US \$ 24 billion and Vietnam at US \$ 16 billion [22].

Contribution of the construction sector in Southeast Asia such as in Indonesia, Singapore, Malaysia, Thailand and the Philippines is known to have an important role for the countries. The construction industry is a significant contributor to the growth of each country's economy. It is directly influenced by government policy because the government can regulate the economy by constructing public works during a period of stagnation [32]. Products from construction provide the necessary public infrastructure and physical structures for various productive activities such as services, trade, utilities and other industries. The construction industry is not only important for finished products, but also requires large numbers of workers (direct and indirect).

Since construction proses in every country has different profit rate and risk, it is important to know what is the rewards and risk for Asian countries. Table 1 shows the comparison of the indexes of each country in Indonesia, Singapore, Malaysia, Thailand, the Philippines and other Asian countries. It can be seen that risk of the construction industry in Indonesia is the highest while the lowest is in the state of Singapore in the fourth for Southeast Asian country. When compared to industrial profits, the highest profit is in the Indonesia while the lowest is in Singapore. Those facts signal to factors that influence the performance of construction companies. 
Table 1 Asia rewards/risk year 2016

\begin{tabular}{lcccccc}
\hline \multicolumn{1}{c}{ Country } & $\begin{array}{c}\text { Industry } \\
\text { rewards }\end{array}$ & $\begin{array}{c}\text { Country } \\
\text { rewards }\end{array}$ & $\begin{array}{c}\text { Industry } \\
\text { risk }\end{array}$ & $\begin{array}{c}\text { Country } \\
\text { risk }\end{array}$ & $\begin{array}{c}\text { Infrastructure } \\
\text { BE rating }\end{array}$ & $\begin{array}{c}\text { Regional } \\
\text { ranking }\end{array}$ \\
\hline China & 72.5 & 60.9 & 40.0 & 69.1 & 65.1 & 3 \\
Korea Selatan & 50.0 & 81.9 & 70.0 & 75.3 & 64.8 & 4 \\
Singapura & 37.5 & 86.2 & 90.0 & 83.2 & 64.0 & 5 \\
Japan & 40.0 & 87.0 & 75.0 & 74.5 & 61.9 & 7 \\
Indonesia & 65.0 & 48.2 & 35.0 & 59.6 & 56.3 & 10 \\
Malaysia & 50.0 & 64.3 & 55.0 & 60.5 & 56.0 & 11 \\
Vietnam & 52.5 & 60.4 & 40.0 & 60.0 & 54.3 & 14 \\
Thailand & 42.5 & 72.3 & 50.0 & 58.9 & 53.7 & 15 \\
Philipines & 50.0 & 55.1 & 35.0 & 64.0 & 52.0 & 17 \\
\hline
\end{tabular}

Note: higher risk score indicates lower risk; Source: BMI report 2016

When competing internationally firms must face challenges due to differences in cultures, project environments, legal and political systems which have significant effect on profit or performance. It is riskier to overcome among countries barrier than domestic ones. Lee et al. (2015) have shown in his research in Korea that, for example, Korean engineering and construction firms have shown different profit performances with respect to host countries for the last 25 years (19902014). It can be seen in Figure 1, the average profit rate (the mean profit rates in a given country) and profit uncertainty (the standard deviation of profit rates) of 2,836 projects which were reported to the International Contractors Association of Korea (ICAK) during the last 25 years (1990-2014). Most projects in Europe, Hong Kong, Mexico, and the United States have resulted in high and stable profit margins (upper left dotted area in Fig.1), whereas projects in the Middle East, developing countries in Asia, and Singapore have shown relatively low and unstable profit margins (lower right dotted area in Fig.1) [26]. There are differences in the performance of the construction industry in several countries. The highest average profit was in Hong Kong and Mexico while the lowest profit was in Saudi Arabia. In Southeast Asian country, the highest profit is in the Philippines while Indonesia and Thailand have similar level of profit. Considerable differences in the uncertainty of profits in ASEAN countries are quite high, which is above $12 \%$. In the Europe, it can be seen that the profit uncertainty is less than $12 \%$ while in Asia and Afrika it is larger than $12 \%$. In short, the trend of profit uncertainty forms negative slope with Europe, Hong Kong, Mexico, and the United States have less profit uncertainty and Asia has larger profit uncertainty (riskier).

Competition in construction services requires the companies to be efficient because it affects the performance of companies in the sector. The construction industry has a variety of specialties that can improve the company's performance compared to other sectors. Characteristics in the construction sector such as: (i) unique project production, (ii) long time related to project completion, (iii) complexity of the construction process, (iv) involvement of various specialized teams integrating various types of companies, (v) uncertainty and risk involved in construction activities (Horta, Camanho 2013). Measurement of construction company performance is a concern of previous researchers (Bassioni et al. 2004; Bassioni et al. 2005; and Balabat et al. 2014). The measurement of company performance in general is divided into two main parts, namely measurement in financial aspects and measurement of market aspects (Bassioni et al. 2004).

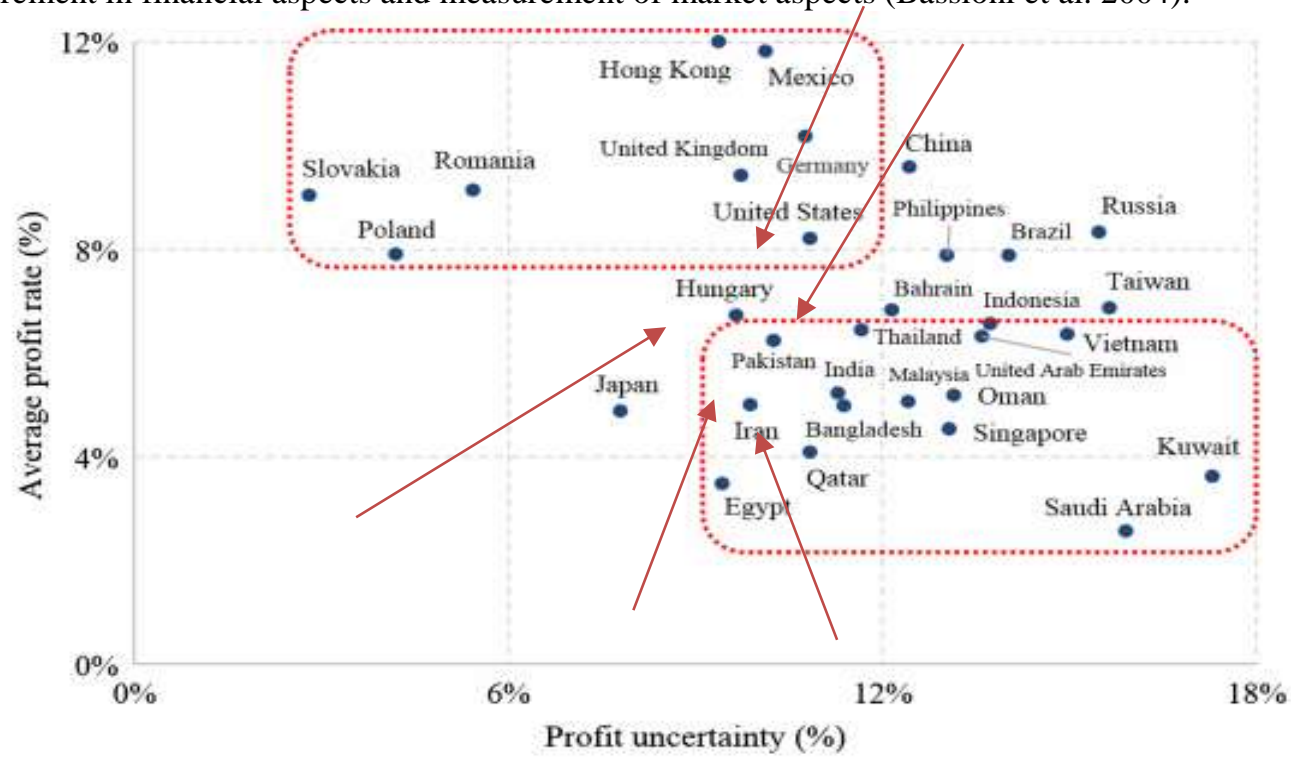

Figure 1 Performance of construction industry in several countries

Source: Lee et al. (2016) 
Balabat et al. (2010) examined the performance of construction companies using market performance (stock returns and market value), profitability ratios and corporate equity valuations. Ocal et al. (2007) reported that there were around 25 ratios of important financial indicators for the construction industry in general. The importance of the ratio is not only different from industry to industry but also from country to country

Many variables both internal and external variables have different influences that affect the performance of construction companies. Measuring construction performance, previous researchers used capital structure variables in in Malaysia [36] and in China [27], corporate management variables in Indonesia [41], solvency variables in Romania [42], market structure variables and ownership structures in China [27], firm concentration in the UK [28], financial ratio variables in Indonesia [34], profit level variables, growth and ownership in the UK [17], macroeconomic variables in Korea [38], economic activity in Spain [31], GDP variables in Ghana [3] [15] [6]. Lee et al. (2016) also showed the differences in company's performance and risk due to the host-country effect in construction companies in Korea. Previous studies have shown the researches that had been carried out in one country or another. This research will focus the study on financial performance and market performance of construction companies in Southeast Asian countries. Indonesia, Singapore, Malaysia, the Philippines and Thailand are selected for the representation of countries in Southeast Asia.

\section{LITERATURE REVIEW}

Performance measurement in construction projects follows three important components in the form of time, cost and scope, correct scope and correct quality [23]. The idea is known as "The Iron Triangle". When the delivery time is on schedule, there is no additional cost, especially labor costs, which is the biggest component in the construction project. Hence, construction will produce good performance. The next element regarding quality, if not according to specifications causes rework and will reduce construction profit. The Cost factor is related to the use of competitive raw materials. Changing one constraint affects the other two for example adding more scope will increase costs and or time. There are many other elements that affect the performance. Those indicators have been studied by many researchers.

Performance indicators are measurable evidence needed to prove that the planned effort has achieved the desired results. A study by Korde et al. 2005, showed a list of performance indicators from the literature including productivity, time, cost, scope, quality, safety, project success and others. Procedures, frameworks, models and guidelines for designing performance indicators appear in many publications on performance measurement. Developing performance indicators that are appropriate to the needs of the organization differ from the characteristics and business processes of each organization. The construction industry is a project-oriented industry where each project is unique and can be considered a prototype, even though a set of processes is involved in each project. There is no single solution or answer exists for all situations with performance that is multifaceted and each framework or method addresses a unique perspective of performance. The benchmark for construction contractor performance indicators is shown in Table 2 .

Performance of construction companies usually analyzed from their financial data. The data can be collected from construction company annual reports at a certain time to determine financial indicators that can be used to analyze industry financial trends. Five independent factors, namely liquidity, capital structure and profitability, activity efficiency, profit margin and growth, and asset structure are identified to be sensitive to economic changes in the country [32]. The results of factor-based analysis can be used both by the government to analyze changes in industry against time and by construction companies to analyze their financial situation in connection with competition in the construction company.

Table 2 Bench mark indicator of contractors' performance

\begin{tabular}{|c|c|}
\hline Type of bench mark & Performance indicator \\
\hline CBPP-KPI & 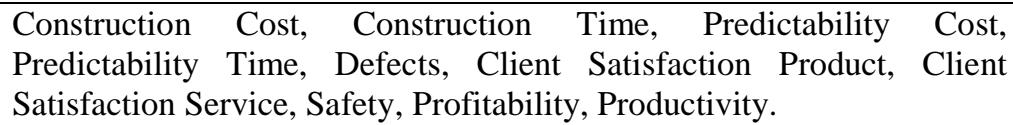 \\
\hline CII-BM\&M & $\begin{array}{l}\text { Project Budget Factor, Project Cost Growth, Project, Schedule Factor, } \\
\text { project Schedule Growth, Recordable Incident rate, Lost work day case } \\
\text { incident rate, Change cost factor, Total field rework factor. }\end{array}$ \\
\hline CII 10-10 & $\begin{array}{l}\text { Planning, Organizing, Leading, Controlling, Design Efficiency, Human } \\
\text { Resources, Quality, sustainability, Supply Chain, Safety. }\end{array}$ \\
\hline
\end{tabular}

Source: Ahmad et al. 2016

The results of previous studies used various company performance indicators. Indicators commonly used in performance measurement of construction companies are financial indicators such as profitability ratios. Other indicators such as consumer satisfaction, environment, growth, business processes are also used in previous studies. The results of the study by Ali et al. (2013) showed that the financial perspective was the best for measuring construction performance. Financial measurements such as profitability, growth, financial stability, cash flow are the most frequently used sequences. Other indicators such as customer perspective, internal business, environment and growth are also used but the ranking 
was not as high as the financial aspect [2]. Other study used financial performance indicator factors such as liquidity, profitability, capital structure, efficiency, growth and asset structure ratios [32]. According to $\mathrm{Ng}$ et al. (2011) the performance of construction companies can be influenced by characteristics of the companies and their external factors.

Industrial performance generally refers to market performance which refers to the extent to which the market produces output that is considered good or favored by the community. Market performance refers to how well the market meets certain social goals and personal goals. Performance in relation to the economy has many aspects but is usually focused on three main aspects, namely efficiency, technological progress and balance in the industry. Efficiency has two main parts, namely internal efficiency and allocation efficiency. The level of internal efficiency describes a well-managed company. This efficiency is measured by the comparison of output value and input value of each company. In contrast to allocation efficiency, it describes the allocation of economic resources in such a way that there is no improvement in production which can increase the output value.

Technological advances and acts of innovation are a form of continuous effort to take actions that provide encouragement for progress. While the balance in the industry is seen in the fulfillment of needs and desires to fulfill the real and valuable expectations and values. The form of interaction between industry structure and behavior will produce good performance and long-term corporate sustainability. Industrial performance refers to the success of the company in producing until it is felt beneficial to consumers [13]. The market will benefit the community if it is able to produce efficient output which is known from the prevailing price level in the market where the price is not much different from the marginal cost of the company in the market.

Performance can also be seen from the pattern of profits obtained by companies in the industry. This pattern of profit can be described by Price-Cost-Margin (PCM). Analysis of the relationship between structure and market performance will try to show the influence of market structure variables on profits proxied by PCM. A high PCM level can only be created if there is a monopoly power or a high concentration ratio.

The performance assessment of the construction industry can be proxied by the construction cost index (CCI). Various studies on CCI have been carried out by various previous studies including Ashuri, Lu (2010), Xu, Moon (2013), and Walsh et al (2005). CCI is a weighted average aggregate of labor price indexes, materials and equipment [12]. CCI can be used as a proxy for the construction industry's performance. CCI also describes the economic and environmental conditions of construction in each market that is different from each market [12] [39]. CCI has been widely used to measure the cost of trends in the construction industry. This index is used as an important input for estimating the construction budget and assessing risks in resource planning and cost management [44].

Knowledge of construction cost trends in the market is important to estimate the effective costs of construction projects. Construction operations are carried out after years of estimated operating costs. Construction operations are generally carried out in a fairly long period. In construction projects it is often difficult to estimate and manage construction costs because construction costs are not static but change dynamically over time. Under certain conditions, a continuous analysis of construction costs is very useful for cost management in construction [21].

\section{METHODOLOGY}

This study uses a quantitative approach. This research was conducted in Jakarta by collecting secondary data needed from the countries of Indonesia, Malaysia, Thailand, the Philippines and Singapore. Quantitative data collection was taken from various information sources such as state banks, the Indonesia Stock Exchange, Singapore Stock Exchange, Malaysia Stock Exchange, Philippine Stock Exchange, Thailand Stock Exchange, Central Bureau of Statistics and the institutions providing information required from year 2013 to year 2016.

Testing the determinants of the performance of construction companies using panel data can be analyzed using panel dynamic and panel static. The construction financial performance uses EBIT/sales as the dependent variables while the construction market performance uses earning yield (EPY or ratio of earning per share to the stock rice) as the dependent variable. The determination of the performance of construction companies utilizes static/dynamic panel model in which the dependent and independent variables are similar to the one presented by Ocal et al. 2007, Ng et al. 2011, Ali et al. 2013, and Bassioni et al. 2005, can be written as follows:

$$
\begin{aligned}
& \text { EBIT } / \text { Sales }_{i t}=\beta_{0}+\beta_{1} D E R_{i t}+\beta_{2} \text { gDomestik } \text { Dit }+\beta_{3} \text { CAR }_{i t}+\beta_{4} g P I_{i t}+\beta_{5} g A S_{i t}+\beta_{6} S B_{i t}+\beta_{7} g E X_{i t}+\beta_{8} E I_{i t} \\
& +\beta_{9} g F D I_{i t}+\varepsilon_{i t} \\
& E P Y_{i t}=\beta_{0}+\beta_{1} D E R_{i t}+\beta_{2} g \text { Domestik }_{i t}+\beta_{3} C A R_{i t}+\beta_{4} g P I_{i t}+\beta_{5} g A S_{i t}+\beta_{6} S B_{i t}+\beta_{7} g E X_{i t}+\beta_{8} E I_{i t} \\
& +\beta_{9} g F D I_{i t}+\varepsilon_{i t}
\end{aligned}
$$

Where:

EBIT/Sales ${ }_{i t}$

EBIT/Sales $i t-1$

$\mathrm{EPY}_{i t}$

$\mathrm{EPY}_{i t-1}$
: EBIT per sales of company i year $t$

: Lag EBIT per sales of company i year t-1

: Earning per share divided by stock price of company i year $t$

: Lag EPY company i year t-1 


$\begin{array}{ll}\mathrm{DER}_{i t} & : \text { Debt equity ratio company i year t-1 } \\ \mathrm{CAR}_{i t} & : \text { Cash to current debt ratio of company i year t } \\ \text { gDomestic }_{i t} & : \text { growth of construction cost per } \mathrm{m}^{2} \text { in country i year } \mathrm{t} \\ \text { gPI }_{i t} & : \text { growth of receivable company i year } \mathrm{t}-1 \\ \mathrm{gAS}_{i t} & : \text { Growth of } \text { asset size company i year } \mathrm{t}-1 \\ \mathrm{SB}_{i t} & : \text { Interest rate at country i year } \mathrm{t} \\ \mathrm{gEX}_{i t} & : \text { Growth of exchange rate against US Dollar at country i year } \mathrm{t} \\ g \mathrm{FDI}_{i t} & : \text { Growth of Foreign Direct Investment country i year } \mathrm{t} \\ \mathrm{EI}_{i t} & : \text { Score of efficiency of company i year } \mathrm{t}\end{array}$

Note: EI is calculated using Data Envelopment Analysis (DEA) with input variables are cost of construction per $\mathrm{m}^{2}$, equity, total cost of operational, and receivable; while output variables include revenue, EBIT, and net profit.

\section{RESULTS AND DISCUSSIONS}

The selected construction company is a company that only conducts a construction service business so as to eliminate construction companies that have subsidiaries / business / property division, rent-housing, manufacture, investment, finance and so on. Determinants of the company's performance are obtained from internal factors or internal conditions of the company, especially the company's financial factors and external factors such as the country's macroeconomics. Internal factors observed consist of DER (Debt to Equty), score of efficiency (EI), cash to current debt ratio (CAR), growth of receivables, and growth of company size (AS). The value of the description analysis is shown in Table 3. It can be seen that DER, receivables and company size are quite varied as seen from the standard deviation and the range that is far enough. The data centering on score of efficiency and CAR is quite good.

Table 3 Description of company's internal factor

\begin{tabular}{lccccc}
\hline Description & DER & EFFICIENTCY & CAR & PI & AS \\
\hline Mean & 2.019779 & 0.897080 & 0.453109 & $1.37 \mathrm{E}+08$ & $6.14 \mathrm{E}+08$ \\
Median & 1.788553 & 0.894759 & 0.235322 & 75038408 & $3.44 \mathrm{E}+08$ \\
Maximum & 14.37889 & 1.000000 & 6.407216 & $6.58 \mathrm{E}+08$ & $4.58 \mathrm{E}+09$ \\
Minimum & 0.085571 & 0.580631 & 0.009144 & 12911515 & 45289855 \\
Std. Dev. & 1.836121 & 0.094268 & 0.839878 & $1.38 \mathrm{E}+08$ & $7.45 \mathrm{E}+08$ \\
Skewness & 3.620237 & -0.817369 & 4.837118 & 1.795035 & 2.578650 \\
Kurtosis & 23.25243 & 3.322774 & 30.76242 & 6.145278 & 11.24980 \\
Jarque-Bera & 1850.341 & 11.10621 & 3457.370 & 91.12549 & 378.6278 \\
Probability & 0.000000 & 0.003875 & 0.000000 & 0.000000 & 0.000000 \\
Observations & 96 & 96 & 96 & 96 & 96 \\
\hline
\end{tabular}

The external factors observed consisted of growth of Foreign Direct Investment (FDI), the growth of exchange rate against the US dollar (EX), interest rates (SB) and growth of construction cost per $\mathrm{m}^{2}$ (Domestic). Table 4 describes the country's external or macroeconomic factors. The highest FDI value is in Singapore compared to other countries under observation. Its value can be up to tens of times that of other countries. The same is true for construction cost per $\mathrm{m}^{2}$ (domestic) in Southeast Asia. In contrast to the exchange rate, the Singapore dollar against the US dollar is the strongest in Southeast Asia with Indonesia having the weakest exchange rate. The interest rates in the five countries are not much different or the variants are low.

The results of the determinants of company financial performance analysis are shown in Table 5. The selection of models that are more appropriate uses the PLS model. Adjusted $\mathrm{R}^{2}$ value is quite low with a value of $36.89 \%$. There are three significant variables that affect the performance of construction companies in Southeast Asia, namely DER, interest rate and score of efficiency, which are internal variables (except for interest rate) of the company. DER's positive influence with performance is also in line with previous studies by Margaritis \& Psillaki (2010) and Tsreng et al. (2012). Construction companies that have a DER or debt at a certain level will certainly increase investor confidence in the construction company. Debt at a certain level indicates that the company is feasible with the creditor who oversees the construction company.

In addition to the company's financial performance, the study also analyzes the market performance of companies with EPY as the proxy. It can be seen in Table 6, the suitable market performance model is PLS. The adjusted $\mathrm{R}^{2}$ model is $14.74 \%$ with three significant variables. The market performance of construction companies in Southeast Asia is influenced by growth of construction cost per $\mathrm{m}^{2}$ (gDomestik), interest rates (SB), and score of efficiency. 
The interest rate clearly affected the finacial performance of construction companies. In construction, the schedule of construction is of prime important since the owner must comply their promised to their tenant. However, many of construction projects due to many reasons delayed their construction hand over. When this situation occurs, many companies suffer from their duty to pay the interest rate due to delayed payment from owner. Debt is one of the tools of capital structures of finance and it can be helpfull if everything is in accordance to the planned schedule.

Other factor that affects the market performance of construction companies is growth of construction cost (gDomestic), this can be explained that there is a demand for growth of the cost and this demand is generated by buyer/owner in the sense that they demnad faster completion and better quality of the buildings. Hence the growth for construction cost is acceptable if it is for better result in quality and faster construction period.

Table 4 Description of companies' external factor (country macro economy)

\begin{tabular}{lcccc}
\hline Description & FDI & EX & SB & DOMESTIC \\
\hline Mean & 16790.36 & 3257.390 & 5.649000 & 775.2917 \\
Median & 10401.50 & 35.84229 & 5.442000 & 672.0000 \\
Maximum & 73987.00 & 13799.27 & 9.212000 & 1720.000 \\
Minimum & 1554.000 & 1.262400 & 2.068000 & 305.0000 \\
Std. Dev. & 20416.03 & 5636.232 & 1.619075 & 315.6712 \\
Skewness & 1.894762 & 1.167178 & 0.242162 & 1.818648 \\
Kurtosis & 5.296646 & 2.381484 & 3.394711 & 5.528379 \\
Jarque-Bera & 78.54032 & 23.32711 & 1.561463 & 78.49047 \\
Probability & 0.000000 & 0.000009 & 0.458071 & 0.000000 \\
Observations & 96 & 96 & 96 & 96 \\
\hline
\end{tabular}

When a company is more efficient, the impact of market confidence is higher so that the earning yield is higher. The results of earning yield studies are in line with Arbitrage Pricing Theory (APT) which was originated from Ross (1976) and Roll and Ross (1980). The APT model conveys the expected return of financial asset data modelled with a linear model with various market factors. The results of the study by Chen, Roll and Ross (1986) show that only 3-5 macroeconomic factors affect the financial return of assets, namely inflation, industrial production index, interest, exchange rate, prices of major commodities (oil and precious metals) and also in line with study of Burmeister and Wall (1986). Testing of macroeconomic drivers to prove APT was also carried out by French (2017) in the ASEAN-5 market (Singapore, Thailand, Philippines, Malaysia and Indonesia) with these 5 macroeconomic factors.

\section{CONCLUDING REMARKS}

The research for determinants performance of construction companies in Southeast Asia concluded that the financial performance of construction companies was influenced by DER, interest rate, and score of efficiency while the company's market performance was influenced by growth of construction cost, interest rates, and efficiency. Further research on the performance of construction companies can use other indicators such as return on assets (ROA), return on equity (ROE), return on invested capital (ROIC), earnings before interest tax depreciation and amortization (EBITDA), net operating profit less adjusted taxes (NOPLAT) while market performance can use equity, dividend per share (DPS), dividend yield (DY), and stock returns.

The results suggest that the government needs to encourage construction companies by improving the bureaucracy process, ease of investment, tax incentives, customs processes, ease of import and certainty of legal process in the construction field. The improvement will reduce the production costs of construction companies and maintain the stability of exchange rates and interest rates. Implications for practitioners is to purchase bulk materials (bulk purchase) to get inexpensive costs. The construction companies can hedge dollars or debt-owed insurance to minimize risk. 
Table 5 Regression results of financial performance of construction companies in Southeast Asia

\begin{tabular}{|c|c|c|c|c|}
\hline \multirow{2}{*}{ Keterangan } & \multicolumn{4}{|c|}{ Panel statis } \\
\hline & PLS & FEM & \multicolumn{2}{|c|}{ REM } \\
\hline \multicolumn{5}{|l|}{$\mathrm{Y}=\mathrm{EBIT} /$ Sales } \\
\hline $\mathrm{C}$ & -0.13189 & 0.08042 & & -0.04151 \\
\hline DER & $\left.0.04582^{* *}\right)$ & $\left.0.01292^{* *}\right)$ & & $\left.0.01442^{* *}\right)$ \\
\hline CAR & -0.02518 & -0.01237 & & -0.01436 \\
\hline gPI & 0.01776 & 0.00202 & & 0.00012 \\
\hline gAS & -0.15079 & 0.02316 & & 0.01897 \\
\hline gDomestik & -0.35275 & 0.13411 & & 0.11554 \\
\hline SB & $\left.-0.00628^{* *}\right)$ & 0.00423 & & 0.00032 \\
\hline $\mathrm{g}(\mathrm{EX})$ & -0.41776 & 0.04081 & & 0.02643 \\
\hline gFDI & 0.00516 & -0.01175 & & -0.01035 \\
\hline Efisiensi & $\left.0.90619^{* *}\right)$ & $\left.0.17891^{* *}\right)$ & & $\left.0.2350^{* *}\right)$ \\
\hline $\mathrm{R}^{2}$ & 0.4286 & 0.9820 & & 0.1689 \\
\hline $\mathrm{R}^{2}$ Adjusted & 0.3689 & 0.9729 & & 0.0819 \\
\hline F-Statistic & 7.1703 & 107.598 & & 1.9423 \\
\hline Prob (F-stat) & 0.0000 & 0.0000 & & 0.0564 \\
\hline Hausman test & \multicolumn{4}{|c|}{ Prob: 0.0002} \\
\hline Uji Chow & \multicolumn{2}{|c|}{ Prob: 0.0000} & & \\
\hline LM test & \multicolumn{4}{|c|}{ Prob: 0.0000000} \\
\hline \multirow{2}{*}{ Keterangan } & \multicolumn{4}{|c|}{ Panel Dinamis } \\
\hline & I & II & III & IV \\
\hline $\mathrm{Y}=\mathrm{EBIT} /$ Sales & $\begin{array}{l}\text { Arellano Bond } \\
\text { (91) }\end{array}$ & GMM smallest & IV meth 3 & IV matrix K.T \\
\hline DER & 0.01922 & $\left.0.02053^{* *}\right)$ & 0.00175 & $0.0195842^{* *)}$ \\
\hline CAR & 0.01405 & 0.01428 & 0.0 & 0.0068302 \\
\hline gPI & -0.02451 & -0.01782 & -0.0838700 & -0.0533617 \\
\hline gAS & 0.00602 & 0.01425 & 0.1371696 & $\left.0.1462563^{* *}\right)$ \\
\hline gDomestik & -0.34138 & -0.23942 & -0.3046331 & -0.1838388 \\
\hline SB & -0.00095 & 0.00039 & -0.0025711 & -0.0050359 \\
\hline $\mathrm{gEX}$ & 0.35914 & 0.38602 & -0.2769407 & 0.0294582 \\
\hline gFDI & -0.00548 & -0.02192 & 0.0417176 & $0.0357454^{* *)}$ \\
\hline Efisiensi & 0.10283 & $\left.0.21779^{* *}\right)$ & 0.1101016 & 0.1797522 \\
\hline Lag Dep & -0.37015 & 0.04615 & -0.9284403 & 0.0963436 \\
\hline $\mathrm{R}^{2}$ & 0.36687 & 0.43592 & 0.1864461 & 0.5514638 \\
\hline $\begin{array}{l}\text { Hansen's J- } \\
\text { statistic }\end{array}$ & 5.64248 & 26.30763 & 1.614796 & 34.1251 \\
\hline P-value & 0.05953 & 0.001819 & 0.2038189 & 0.00017589 \\
\hline
\end{tabular}

Ket: ${ }^{* *} \operatorname{sig} .5 \%,{ }^{*} \operatorname{sig} .10 \%$ 
Table 6 Regression results for market performance of construction companies in Southeast Asia

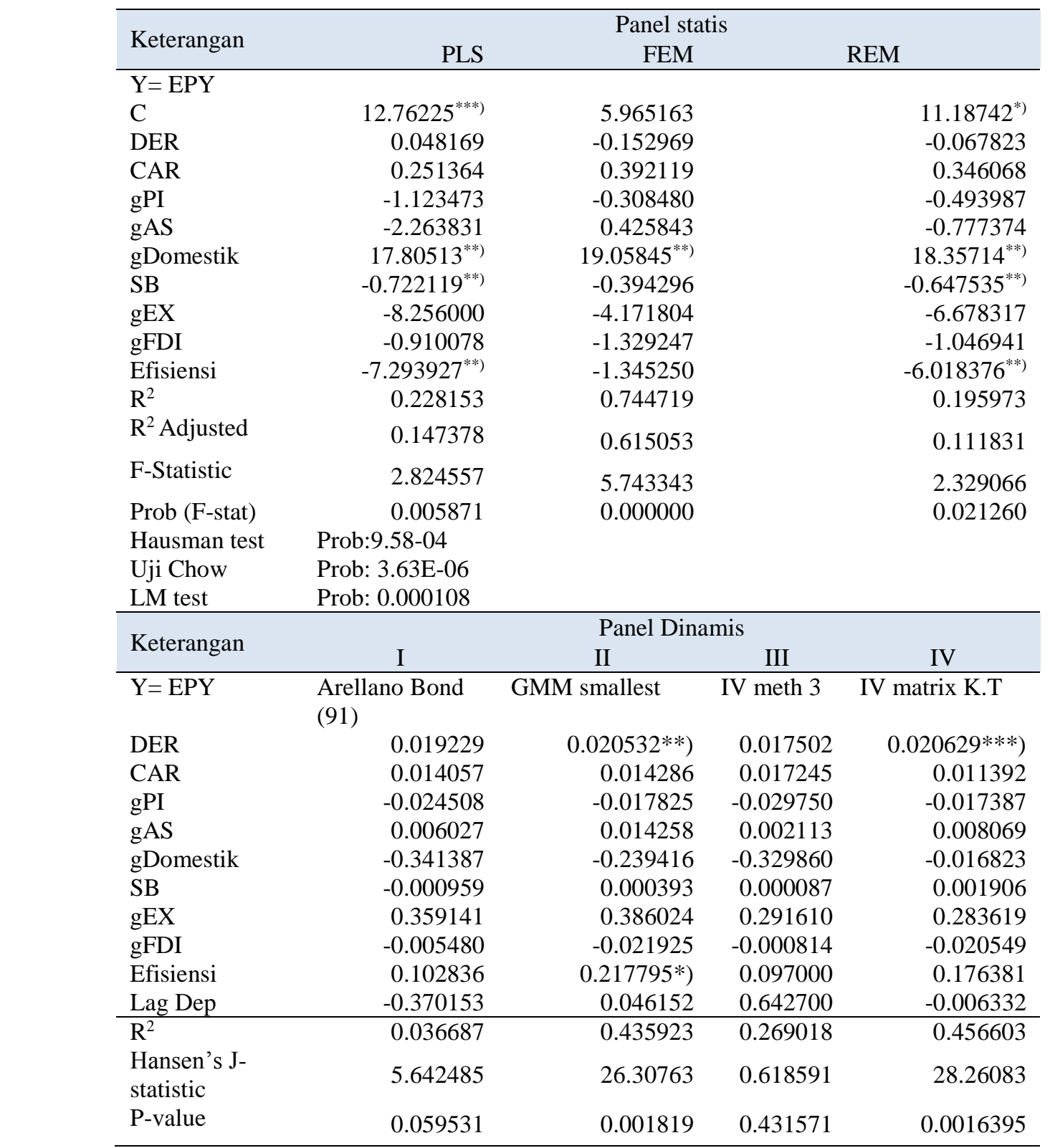

Ket: ${ }^{* *}$ sig. $.5 \%,{ }^{*}$ sig. $10 \%$ 


\section{REFERENCES}

[1] Ahmad SBS, Svalestuen F, Andersen B, Torp O. 2016. A review of performance for successful concurrent construction. Procedia Social and Behavioral Science. 226:447-454.

[2] Ali HAE, Al-Sulaihi IA, Al-Ghantani KS. 2013. Indicator of measuring performance of building construction companies in Kingdom of Saudi Arabia. Journal of Jing Saud University-Engineering Science. 25:125-134.

[3] Anaman KA, Osei-Amponsah C. 2007. Analysis of the causality link between the growth of the construction industry and the growth of macro-economy in Ghana. Construction Management and Economics. 25:951-961.

[4] Ashuri B, Lu J. 2010. Time series analysis of ENR construction cost index. J. Constr. Eng. Manage. 136:1227-1237.

[5] Balatbat MCA, Lin CY, Carmichael DG. 2010. Comparative performance of publicly listed construction companies: Australian evidence.

Construction Management and Economics. 28:919-932.

[6] Barber HM, El-adway IH. 2014. Economic performance assessment for the construction industry in the Southeastern United States. J.Manage.Eng. 05014014:1-6.

[7] Bassioni HA, Price ADF, Hasan TM. 2004. Performance measurement in construction. Journal Manage.Eng. 20:4250.

[8]__. 2005. Building a conceptual framework for measuring business performance in construction: an empirical evaluation.

Construction

Management

and Economic. 23:495-507.

[9] Business Monitor International Research. 2016 [BMI]. Indonesia Infrastructure Report 2016. London (UK): BMI Research

[10] Badan Pusat Statistika [BPS]. 2015. Statistik Indonesia 2015. Jakarta (ID): BPS.

[11] Burmeister E, Wall KD. 1986. The arbitrage pricing theory and macroeconomic factor measures. The Financial Review. 21(1):1-20

[12] Cao MT, Cheng MY, Wu YW. 2014. Hybrid computational model for forecasting Taiwan construction cost index. $J$. Constr. Eng. Manage. 04014089:1:11

[13] Carlton DW, Perloff JM. 2000. Modern Industrial Organization $3^{\text {rd }}$ Edition. New York (US): Addison Wesley Longman, Inc

[14] Chen NF, Rool R, Ross SA. 1986. Economic forces and stock market. The Journal of Business. 59(3):383-403.

[15] Chia FC. 2012. Construction and economic development: the case of Malaysia. The International Journal of Construction Management. 12(1):23-35.

[16] Coban O, Ustundag E, Coban A. 2015. The structural analysis of construction sector of turkey and its effect on the selected macroeconomic indicators. Copernican Journal of Finance \& Accounting. 4(1):27-44.

[17] Deng F, Smyth H. 2013. Nature of firm performance in construction. J. Constr. Eng.Manage. 04013040:1-14

[18] Firmawan F, Othman F, Yahya K. 2012. Framework for green construction assessment: a case study of government institution building project in Jakarta, Indonesia. Journal of Emerging Trends in Engineering and Applied Sciences. 3(4):576-580.

[19] French J. 2017. Macroeconomic forces and arbitrage pricing theory. Journal of Comparative Asian Development. $16(1): 1-20$.

[20] Horta IM, Camanho AS. 2013. Company failure prediction in the construction industry. Expert System with Applications. 40:6253-6257.

[21] Hwang S. 2011. Time series models for forecasting construction costs using time series indexes. International Conference on Intelligent Computation Technology and Automation. J. Constr. Eng.Manage. 137:656-662.

[22] Ministry of Trade of Indonesia (Kementerian Perdagangan /Kemendag). 2015. Kesiapan Sektor Konstruksi Nasional Menghadapi Masyarakat Ekonomi ASEAN 2015. Jakarta (ID). Direktorat Perundangan Perdagangan Jasa, Kemendag.

[23] Kliem RL, Ludin IS, Robertson KL.1997. Project Management Methodology A Practical Guide for The Next Millennium. New York (US): Taylor \& Francis Group LLC

[24] Korde T, Li M, Russell AD. .2005. State-of-the-Art review of construction performance models and factors. Paper presented at the Construction Research Congress.

[25] Lee KW, Han SH, Park H, Jeong HD. 2016. Empirical analysis of host-country effects in the international construction market: an industry-level approach. Journal Construction Engineering Management. 04015092:1-10.

[26] Liu W, Gao Y, Fu H. 2014. Empirical study of the capital structure's impact on corporate performance of listed real estate companies. ICCREM 2014: Smart Construction and Management in the Context of New Technology. 1047 1057.

[27] Liu YS, Zhao XF, Liao YP. 2013. Market structure, ownership structure and performance of China's construction industry. Journal of Construction and Management. 139:852-857.

[28] Lowe J. 2011. Concentration in the UK construction sector. Journal of Financial Management of Property and Construction. 16(3):232-248. 
[29] PT. Langdon \& Seah Indonesia [LSI]. 2016. Construction Cost Handbook Indonesia 2016. Jakarta (ID): Arcadis Indonesia.

[29] Margaritis D, Psillaki M. 2010. Capital structure, equity ownership and firm performance. Journal of Banking \& Finance. 34:621-632

[30] Navarro-Gracia JC, Madrid-Guijarro A. 2016. Real economic activity and accounting information in Spanish construction and real estate firms. Revista de Contabilidad Spanish Accounting Review. 19(1):21-30.

[31] Ng ST, Wong JMW, Zahng J. 2011. Applying Z-score model to distinguish insolvent construction companies in China. Habita International. 35:599-607.

[32] Ocal ME, Oral EL, Erdis E, Vural G. 2007. Industry financial ratio application of factor analysis in Turkish construction industry. Building and Enviroment. 42:385-392.

[33] Pamulu MP. Kajewski S, Betts M. 2007. Evaluating financial ratio in construction industry: a case study of Indonesia Firm. Proceeding $1^{\text {st }}$ International Conference of European Asian Civil Engineering Forum. E-158, Jakarta.

[34] Ramanathan R. 2003. An Introduction to Data Envelopment Analysis A Tool for Performance Measurement. New Delhi (IN): Sage Publications.

[35] Roll R, Ross SA. 1980. An empirical investigation of the arbitrage pricing theory. The Journal of Finance. 35(5):10731103

[36] Ross SA. 1976. The Arbitrage theory of capital asset pricing. Journal of Economic Theory. 13:341-380.

[37] San OT, Heng TB. 2011. Capital structure and corporate performance of Malaysian construction sector. International Journal of Humanities and Social Science. 1(2):28-36.

[38] Sang J, Ham NH, Kim JH, Kim JJ. 2014. Impacts of macroeconomic fluctuations on insolvency: case of Korean construction companies. Journal Manage.Eng. 05014009:1-10.

[39] Serestha MZ, Akbarijokar M, Khosravi S, Afshari H. 2014. Construction project success ranking through the data envelopment analysis. Journal of Data Envelopment Analysis and Decision Science. 2014:1-13.

[40] Tserng HP, Liao HH, Jaselskis EJ, Tsal LK, Chen PC. 2012. Prediction construction contractor default with barrier option model. Journal of Construction Engineering and Management. 138:621-630.

[41] Veronika A, Riantini LS, Firmansyah BA. 2008. Identification of the factors in corporate management that influence construction company's performance in Indonesia. Innovation in Structural Engineering and Construction. 1363-1367.

[42] Vasiu DE, Gheorghe I. 2014. Case study regarding solvency analysis, during 2006-2012, of the companies having the business line in industry and construction, listed and traded on the Bucharest Stock Exchange. Procedia Economic and Finance. 16:258-269.

[43] Walsh KD, Sawhney A, Brown A. 2005. International comparison of cost for the construction sector: purchasing power parity. Journal of Construction Engineering and Management. 131:160-167.

[44] Xu JW, Moon S. 2013. Stochastic forecast of construction cost index using a cointegrated vector autoregression model. Journal of Management in Engineering. 29:10-18. 